\title{
Upregulated expression of MMP-9 in gingival epithelial cells induced by prolonged stimulation with arecoline
}

\author{
OSAMU UEHARA ${ }^{1}$, KOUSUKE TAKIMOTO ${ }^{2}$, TETSURO MORIKAWA $^{3}$, FUMIYA HARADA ${ }^{3}$, RIE TAKAI $^{3}$, \\ BHOJ RAJ ADHIKARI ${ }^{3}$, RYOKO ITATSU ${ }^{3}$, TOMOHISA NAKAMURA ${ }^{3}$, KOKI YOSHIDA $^{3}$, HIROFUMI MATSUOKA ${ }^{1}$, \\ HIROKI NAGAYASU ${ }^{2}$, ICHIRO SAITO ${ }^{4}$, MALSANTHA MUTHUMALA ${ }^{5}$, ITSUO CHIBA ${ }^{1}$ and YOSHIHIRO ABIKO ${ }^{2}$ \\ ${ }^{1}$ Division of Disease Control and Molecular Epidemiology, Department of Oral Growth and Development; \\ Divisions of ${ }^{2}$ Oral and Maxillofacial Surgery and ${ }^{3}$ Oral Medicine and Pathology, Department of Human \\ Biology and Pathophysiology, School of Dentistry, Health Sciences University of Hokkaido, Tobetsu, \\ Hokkaido 061-0293; ${ }^{4}$ Department of Pathology, Tsurumi University School of Dental Medicine, Yokohama, \\ Kanagawa 230-8501, Japan; ${ }^{5}$ Department of Oral and Maxillofacial Surgery, Army Hospital, Colombo, Sri Lanka
}

Received April 25, 2016; Accepted March 23, 2017

DOI: $10.3892 / \mathrm{ol} .2017 .6194$

\begin{abstract}
Betel quid chewing is implicated in the high prevalence of oral cancer in Southeast Asian countries. One of the major components of betel quid is arecoline. In the present study, in order to characterize the association between chronic arecoline stimulation and carcinogenesis the expression level of matrix metalloproteinase (MMP)-2, MMP-9, tissue inhibitor of metalloproteinase (TIMP)-1 and TIMP-2 mRNA in human gingival epithelial progenitor cells (HGEPs) stimulated with arecoline was assessed. The HGEPs were alternated between 3 days of incubation with arecoline $(50 \mu \mathrm{g} / \mathrm{ml})$, and 3 days without arecoline, for up to 30 days. The expression levels of the MMPs and TIMPs in the cells stimulated with arecoline were evaluated by reverse transcription-quantitative polymerase chain reaction at 18 and 30 days. The expression of MMP-9 mRNA in the experimental group was significantly increased compared with in the control group $(\mathrm{P}<0.01)$. No significant differences in the expression of MMP-2, TIMP-1 or TIMP-2 mRNA were observed between the experimental and control groups. Using an MMP-9 activity assay, the levels of MMP-9 activity in the experimental group were demonstrated to be significantly higher than in the control group $(\mathrm{P}<0.05)$. To investigate associated cellular signaling pathways, PDTC [a nuclear factor (NF) $\kappa \mathrm{B} /$ inhibitor of $\mathrm{NF}-\kappa \mathrm{B}$ (IкB) inhibitor], PD98059 [a mitogen-activated protein kinase
\end{abstract}

Correspondence to: Professor Yoshihiro Abiko, Division of Oral and Maxillofacial Surgery, Department of Human Biology and Pathophysiology, School of Dentistry, Health Sciences University of Hokkaido, 1757 Kanazawa, Ishikari, Tobetsu, Hokkaido 061-0293, Japan

E-mail: yoshi-ab@hoku-iryo-u.ac.jp

Key words: betel quid chewing, arecoline, epithelial cells, MMP-9, prolonged stimulation kinase (MAPKK)1 and MAPKK2 inhibitor], SB203580 (a p38 MAPK inhibitor) and 5,15-DPP [a signal transduction and activator of transcription (STAT) 3 inhibitor] were used. All inhibitors decreased the extent of MMP-9 upregulation induced by stimulation with arecoline. Based on the data, it is hypothesized that MMP-9 activity may be involved in the pathological alterations of oral epithelium induced by betel quid chewing, and that the NF- $\mathrm{B} / \mathrm{I} \kappa \mathrm{B}, \mathrm{MAPK}$, p38 MAPK and STAT3 signaling pathways may be involved in the production of MMP-9 induced by betel quid chewing.

\section{Introduction}

Oral cancer is one of the 10 most commonly occurring types of malignant tumor worldwide, particularly in Southeast Asian countries (1). The habit of betel quid chewing is implicated in the high prevalence of oral cancer in these countries. Betel quid consists of a mixture of fresh areca nut, slaked lime from seashells, fresh betel leaf and partially dried tobacco (2-4). The association of these components with oral carcinogenesis remains unclear. Areca nut and its component arecoline, a nicotinic acid-based alkaloid, have been reported to promote oral cancer and precancerous lesions (5). Areca nut extract and arecoline induce the upregulation of various growth factors, enzymes and other molecules associated with oral submucous fibrosis, a precancerous condition (6), and stimulate oral cancer cells and immortalized cell lines to express molecules associated with cancer progression $(7,8)$. Our previous studies analyzed p14, p15, p16 and p53 genes in precancerous oral lesions associated with betel quid chewing in Sri Lanka $(1,9,10)$. A high frequency of hypermethyaltion of p14, p15 and p16 was detected in the pre-cancerous lesions. The frequency was much higher than that of p53 mutation.

Matrix metalloproteinase (MMP) and tissue inhibitor of metalloproteinase (TIMP) may be key molecules in oral submucous fibrosis (11) and cancer (7). The exact mechanism for the malignant transformation of healthy oral epithelium remains unclear. MMPs serve an important function in the degradation 
of the extracellular matrix (ECM), a process crucial for tumor growth, invasion and metastasis. The MMP family includes $\geq 28$ members, which may be classified as gelatinases, collagenases, membrane-type MMPs, stromelysins or matrilysins, based on substrate specificity and their sequence homology $(12,13)$. The association of the gelatinases, including MMP-2 and MMP-9, with the development and progression of cancer is well documented $(12,13)$. The enzymatic activity of MMPs is controlled by TIMPs. A total of 4 types of TIMP have been characterized, including TIMP-1,-2,-3 and -4. TIMP-1 and TIMP-2 are capable of inhibiting the activity of all non-membrane-type MMPs, including MMP-2 and MMP-9 $(12,13)$. The increased MMPs and the decreased inhibitors may facilitate tumor development and progression $(12,13)$. In order to determine the mechanism of arecoline-induced malignant transformation, it is crucial to observe the expression pattern of MMP-2, MMP-9, TIMP-1 and TIMP-2.

Malignant transformation may occur following chronic stimulation with carcinogenic agents. However, in previous in vitro experiments cells were stimulated with arecoline for $<30 \mathrm{~h}$, which elicited an acute response as an experimental model for arecoline stimulation $(7,14)$. Since the malignant transformation occurs as a chronic event induced by the stimulation with arecoline, cells should be stimulated for a prolonged period in vitro. Cell death may be induced by stimulation for a prolonged period with arecoline, since arecoline has a cytotoxic effect $(7,8,11,15,16)$. In our previous study, we developed a novel in vitro model to simulate chronic cell stimulation over a prolonged period (17).

In the present study, this in vitro modeling method from our previous study was used to simulate chronic arecoline stimulation and the expression of MMP-2, MMP-9, TIMP-1 and TIMP-2 was measured. The pathway of aberrant expression of molecules involved in carcinogenesis often can be a therapeutic target $(12,13)$. Therefore, the present study also observed the pathway of the aberrant expression of MMPs and TIMPs.

\section{Materials and methods}

Cell culture. Human gingival epithelium progenitors (HGEPs), primary keratinocytes derived from healthy gingival epithelium, were purchased from CELLnTEC Advanced Cell Systems AG (Basel, Switzerland) and were cultured in CnT-Prime epithelial culture medium (CELLnTEC Advanced Cell Systems $\mathrm{AG}$ ) at $37^{\circ} \mathrm{C}$ in a humidified atmosphere of $95 \%$ air and $5 \% \mathrm{CO}_{2}$. HGEPs were spread onto $100 \mathrm{~mm}$ tissue culture plates at a density of $4 \times 10^{4}$ cells $/ \mathrm{ml}$. Following incubation overnight, the cells were cultured with arecoline hydrobromide (Sigma-Aldrich; Merck KGaA, Darmstadt, Germany) and the following inhibitors: $50 \mu \mathrm{M}$ nuclear factor

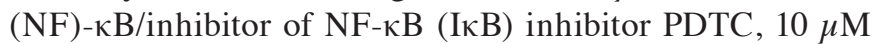
mitogen-activated protein kinase (MAPK) kinase inhibitor PD98059, $25 \mu \mathrm{M}$ p38 MAP kinase inhibitor SB203580, and $10 \mu \mathrm{M}$ signal transducer and activator of transcription (STAT) 3 inhibitor VIII 5,15-DPP (all from Sigma-Aldrich; Merck $\mathrm{KGaA})$.

Cell viability assays. Cell viability was determined using the cell proliferation reagent WST-1 (Sigma-Aldrich; Merck
KGaA). HGEPs were seeded in 96-well plates in epithelial culture medium and cultured overnight as previously described. The cells were treated with a range of arecoline concentrations (including 0, 0.5, 1, 5, 10, 50, 100, 500, 1,000, $5,000$ and $10,000 \mu \mathrm{g} / \mathrm{ml})$. The arecoline was dissolved in distilled water. Following incubation for 24,48 or 72 h, $10 \mu \mathrm{l}$ of WST-1 was added to each well and cultured for $1 \mathrm{~h}$. The absorbance at $450 \mathrm{~nm}$ was determined using a Model 680 Microplate Reader (Bio-Rad Laboratories, Inc., Hercules, CA, USA).

RNA extraction. Cell culture medium was replaced every 3 days, alternating with and without $50 \mu \mathrm{g} / \mathrm{ml}$ arecoline for 1 month. Untreated samples were used as controls. The inhibitors $(50 \mu \mathrm{M}$ of the NF- $\kappa \mathrm{B} / \mathrm{I} \kappa \mathrm{B}$ inhibitor PDTC, $10 \mu \mathrm{M}$ of the MAPK kinase inhibitor PD98059, $25 \mu \mathrm{M}$ of the p38 MAPK inhibitor SB203580 or $10 \mu \mathrm{M}$ of the STAT 3 inhibitor VIII 5,15-DPP) were added to the culture medium for 18 days (added on day 3, 9 and 15). The culture was replaced by alternating 3 days with arecoline and 3 days with the inhibitors. Total RNA was extracted from the HGEPs using RNeasy ${ }^{\circledR}$ Mini kit (Qiagen GmbH, Hilden, Germany) according to the manufacturer's protocol. Total RNA of $2 \mu \mathrm{g}$ was reverse transcribed into cDNA using an ReverTra Ace ${ }^{\circledR}$ qPCR RT Master Mix (Toyobo Co., Ltd., Osaka, Japan), following the manufacturer's protocol.

Quantitative polymerase chain reaction ( $q P C R)$. For PCR, cDNA $(1 \mu \mathrm{l})$ was mixed with FastStart Essential DNA Green Master (Roche Diagnostics) and the relevant primers. The cDNA levels were measured using the LightCycler ${ }^{\circledR}$ Nano System (Roche Diagnostics, Basel, Switzerland). The PCR primers (Eurofins Genomics, Tokyo, Japan) for GAPDH, MMP-2, MMP-9, TIMP-1 and TIMP-2 are exhibited in Table I. The PCR was performed using the LightCycler ${ }^{\circledR}$ Nano System (Roche Diagnostics), and conditions included an initial incubation at $50^{\circ} \mathrm{C}$ for $2 \mathrm{~min}$, denaturing at $95^{\circ} \mathrm{C}$ for $10 \mathrm{~min}$, then 40 cycles of denaturing at $95^{\circ} \mathrm{C}$ for $15 \mathrm{sec}$ and annealing at $60^{\circ} \mathrm{C}$ for $1 \mathrm{~min}$. The relative expression of each mRNA was calculated by comparison to GADPH mRNA using the $2^{-\Delta \Delta C q}$ method (18). Data are expressed as the relative amount of target mRNA compared with GAPDH mRNA. A total of 3 repetitions of the experimental culture system were performed in order to extract RNA. RT-qPCR of each experimental culture system was carried out 3 times and the mean was used.

Supernatant MMP-2 and MMP-9 activity assay. MMP-2 and MMP-9 activity were measured using an MMP-2 and MMP-9 activity assay kits (QuickZyme Biosciences, Leiden, Netherlands) according to the manufacturer's protocol. Absorbance values at $405 \mathrm{~nm}$ were determined with a Model 680 Microplate Reader (Bio-Rad Laboratories, Inc.), and standard curves relating concentration (MMP-9, 0.01-16 ng/ml; MMP-2, $0.02-16 \mathrm{ng} / \mathrm{ml}$ ) in $\mathrm{ng} / \mathrm{ml}$ to absorbance values were plotted. In total, 3 experimental culture systems were performed to measure MMP-2 and MMP-9 activity. The MMP-2 and MMP-9 activity assays for each experimental culture system were carried out 3 times and the mean was used.

Statistical analysis. Statistical analysis was performed using SPSS version 23 (IBM SPSS, Armonk, NY, USA). Results were 
Table I. Primer sequences (5' to $\left.3^{\prime}\right)$.

\begin{tabular}{lllc}
\hline Gene & \multicolumn{1}{c}{ Forward } & \multicolumn{1}{c}{ Reverse } & (Refs.) \\
\hline GAPDH & GTGAAGGTCGGAGTCAAC & GTTGAGGTCAATGAAGGG & $(31)$ \\
$M M P-2$ & CAAGGACCGGTTATTTGGC & ATTCCCTGCGAAGAACACAGC & $(32)$ \\
$M M P-9$ & TTGACAGCGACAAGAAGTGG & GCCATTCACGTCGTCCTTAT & $(33)$ \\
$T I M P-1$ & GGGACACCAGAAGTCAACCA & GGCTTGGAACCCTTTATACATC & $(34)$ \\
$T I M P-2$ & AAGCGGTCAGTGAGAAGGAA & TCTCAGGCCCTTTGAACATC & $(34)$ \\
\hline
\end{tabular}

MMP, matrix metalloproteinase; TIMP, tissue inhibitor of metalloproteinase.

compared using the Mann-Whitney U test. Data are presented as the mean \pm standard deviation. $\mathrm{P}<0.05$ was considered to represent a statistically significant difference.

\section{Results}

Cell viability at a range of arecoline concentrations. To determine a concentration of arecoline that was suitable for the treatment of cells over a prolonged period, cell viability in different concentrations of arecoline [including 0 (control), $0.5,1,5,10,50,100,500,1,000,5,000$ and $10,000 \mu \mathrm{g} / \mathrm{ml}]$ was initially observed. The number of viable cells was estimated by a WST-1 assay after 24,48 or $72 \mathrm{~h}$ of arecoline treatment (Fig. 1). At doses of $\leq 100 \mu \mathrm{g} / \mathrm{ml}$ of arecoline, cell numbers increased in a time-dependent manner. No significant differences were observed in cell numbers at the same time point between any concentration of arecoline at $\leq 100 \mu \mathrm{g} / \mathrm{ml}$ and the control. Cell viability was significantly lower in the $\geq 500 \mu \mathrm{g} / \mathrm{ml}$ arecoline groups compared with the $\leq 100 \mu \mathrm{g} / \mathrm{ml}$ group $(\mathrm{P}<0.05)$. Since arecoline at the concentration of $50 \mu \mathrm{g} / \mathrm{ml}$ had no cytotoxic effect on the cells stimulated, even for a prolonged period, the method of alternating between 3 days with $50 \mu \mathrm{g} / \mathrm{ml}$ of arecoline and 3 days without arecoline for 1 month was selected. Additionally, the cells were observed using phase contrast microscope (magnification, $x 400$ ). No significant morphological changes were observed in cells stimulated with arecoline for 1 month, compared with the controls (Fig. 2). A number of rounded cells were often observed in the cells stimulated with arecoline after 9 days (Fig. 2).

MMP-9 is significantly upregulated in cells treated with arecoline. The expression levels of MMP-2, MMP-9, TIMP-1 and TIMP-2 in cells treated with $50 \mu \mathrm{g} / \mathrm{ml}$ arecoline were evaluated by quantitative RT-PCR at 18 and 30 days. No significant differences in the expression of MMP-2 mRNA was observed between the experimental and control groups (Fig. 3A). The expression of MMP-9 mRNA in the experimental group was significantly increased compared with the control group $(\mathrm{P}<0.001$; Fig. 3B). No significant difference in the expression of TIMP-1 (Fig. 3C) or TIMP-2 (Fig. 3D) mRNA was observed between the experimental and control groups.

MMP-9 activity is significantly increased in cells treated with arecoline. MMP-2 and MMP-9 activity was assessed with MMP-2 and MMP-9 activity assays. No significant difference in the levels of MMP-2 activity was observed between

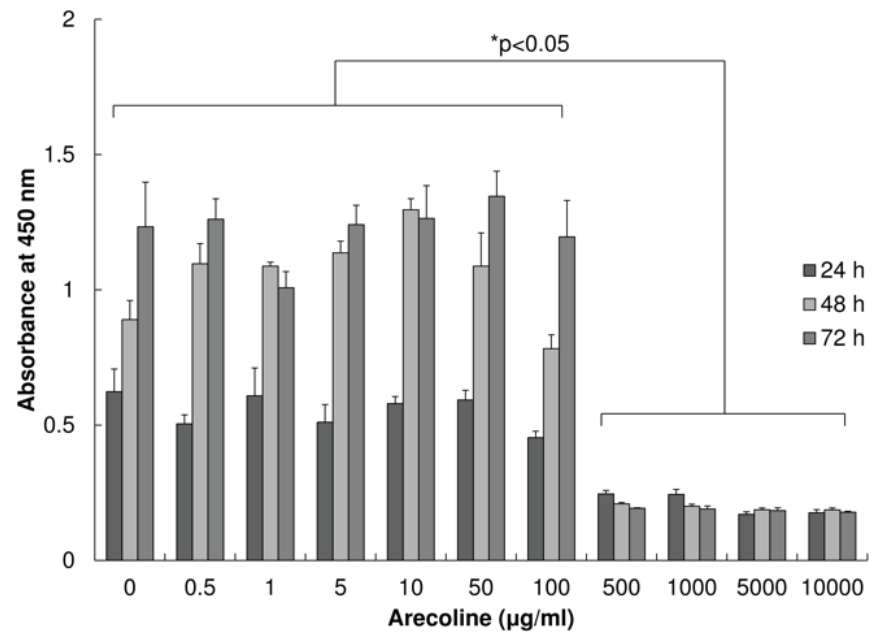

Figure 1. Cell viability assays. Cell numbers were estimated by WST-1 assays subsequent to treatment with arecoline at a range of concentrations for 24,48 and $72 \mathrm{~h}$. At concentrations of arecoline $\leq 100 \mu \mathrm{g} / \mathrm{ml}$, the cell numbers increased in a time-dependent manner. No significant differences in cell numbers at the same time point were observed between the control $(0 \mu \mathrm{g} / \mathrm{ml})$ and experimental groups for any concentration of arecoline. The cell numbers were significantly lower following treatment with $\geq 500 \mu \mathrm{g} / \mathrm{ml}$ arecoline, when compared with the control.

the experimental and control groups (Fig. 4A). The levels of MMP-9 activity in the experimental group were significantly increased compare with the control group $(\mathrm{P}<0.05 ;$ Fig. 4B).

Inhibition of signaling pathways reduces the upregulation of MMP-9 in cells treated with arecoline. To investigate cellular signaling pathways that may mediate the observed effect of arecoline on MMP-9 expression and activity, signal pathway inhibitors were employed, including the NF- $\mathrm{\kappa B} / \mathrm{I} \kappa \mathrm{B}$ inhibitor PDTC, the MAPK kinase inhibitor PD98059, the p38 MAPK inhibitor SB203580 and the STAT3 inhibitor 5,15-DPP. All inhibitors decreased the extent of MMP-9 upregulation induced by stimulation with arecoline. PDTC and PD98059 partially inhibited the upregulation of MMP-9, whereas SB203580 and 5,15-DPP completely abolished the upregulation $(\mathrm{P}<0.01$; Fig. 5$)$.

\section{Discussion}

The present study investigated the expression of MMP-2, MMP-9, TIMP-1 and TIMP-2 in primary keratinocytes 


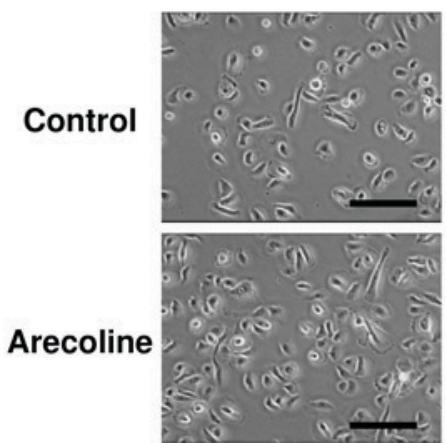

3 days

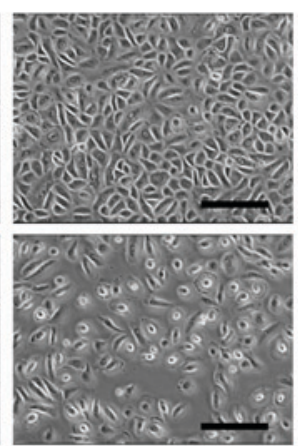

9 days

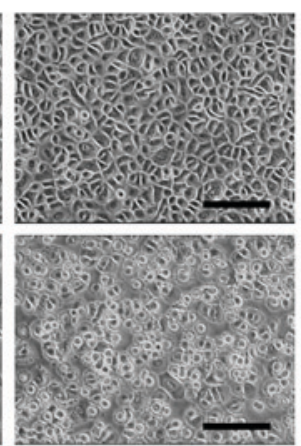

18 days

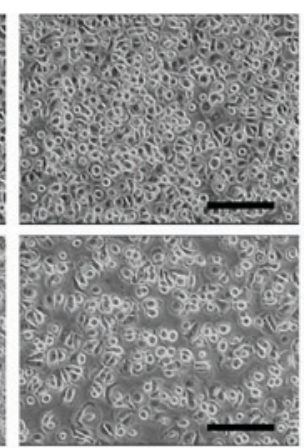

24 days

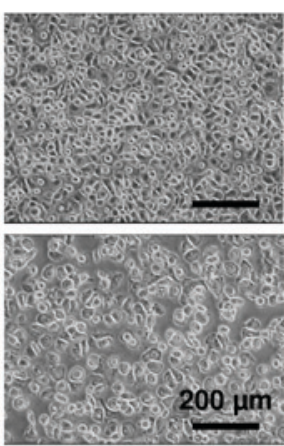

30 days

Figure 2. Morphological changes. Based on the data from the cell viability assays, cells were alternated between 3 days with $50 \mu \mathrm{g} / \mathrm{ml}$ of arecoline and 3 days without arecoline, for 1 month. No significant morphological changes were observed in the cells stimulated with arecoline for 1 month, compared with untreated cells. Although, a number of rounded cells were observed in the cells stimulated with arecoline after 9 days. Scale bar=200 $\mu \mathrm{m}$.
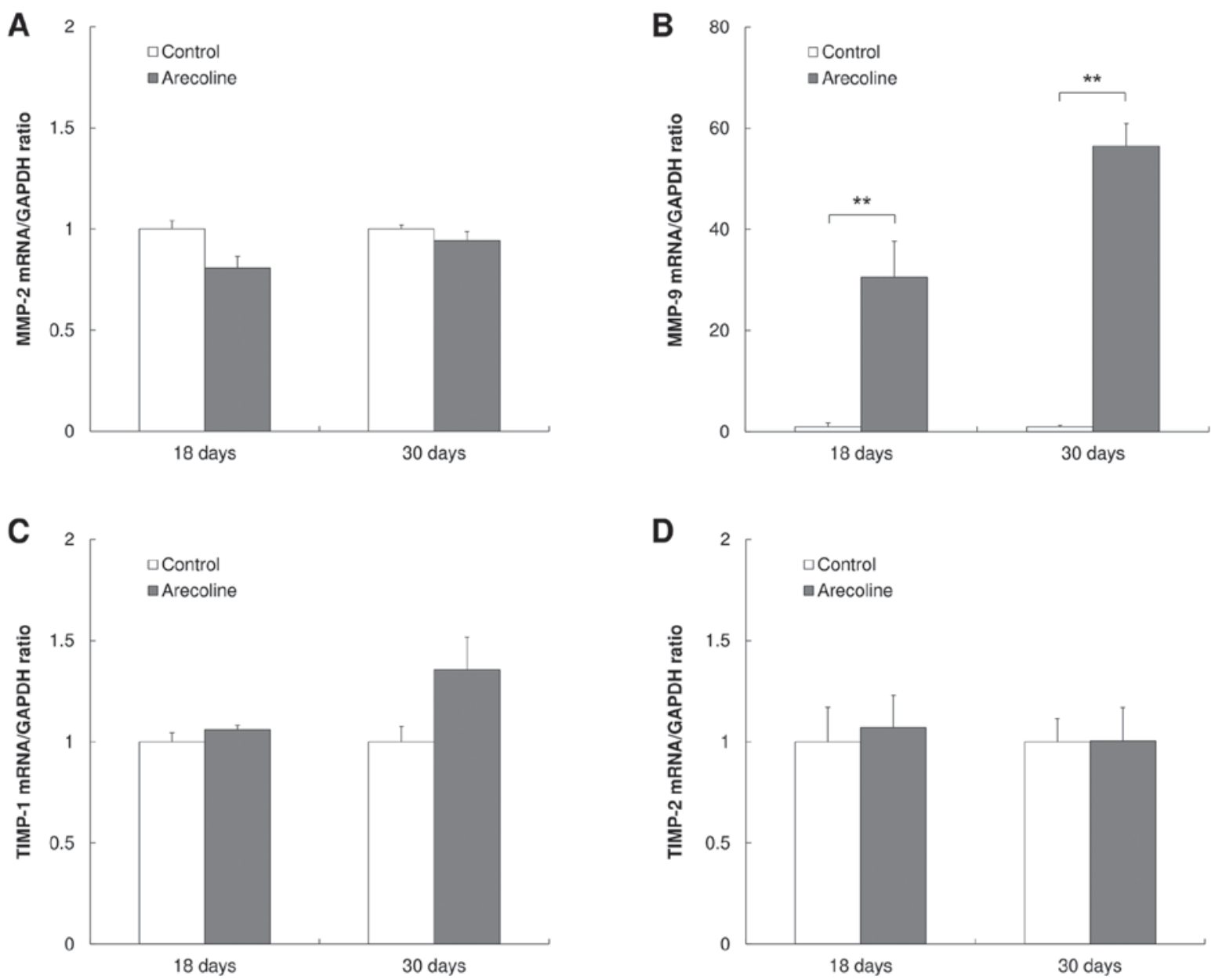

Figure 3. Expression level of MMP-2, MMP-9, TIMP-1 and TIMP-2 mRNA in HGEPs. (A) No significant differences in the expression of MMP-2 mRNA were observed between the experimental and control groups. (B) The expression of MMP-9 mRNA in the experimental group was significantly increased compared with the control group. No significant differences in the expression of (C) TIMP-1 or (D) TIMP-2 mRNA were observed between the experimental and control groups. ${ }^{* *} \mathrm{P}<0.01$ compared with untreated cells. MMP, matrix metalloproteinase; TIMP, tissue inhibitor of metalloproteinase; HGEP, human gingival epithelium progenitors.

derived from healthy gingival epithelium stimulated with arecoline for a prolonged period. MMP-9 mRNA expression and activity were upregulated by stimulation with arecoline. MMP-9 activity may be involved in an initial stage of the transformation of normal cells to oral cancer and the development of precancerous lesions induced by betel quid chewing.
Arecoline was previously demonstrated to promote fibrosis in the oral submucosa and the progression to oral cancer (19). The majority of the other in vitro studies have used oral cancer-derived cells and immortalized cells to observe the effect of arecoline on oral epithelial cells, not primary cells $(7,8)$. These studies exhibited the effect of arecoline on 

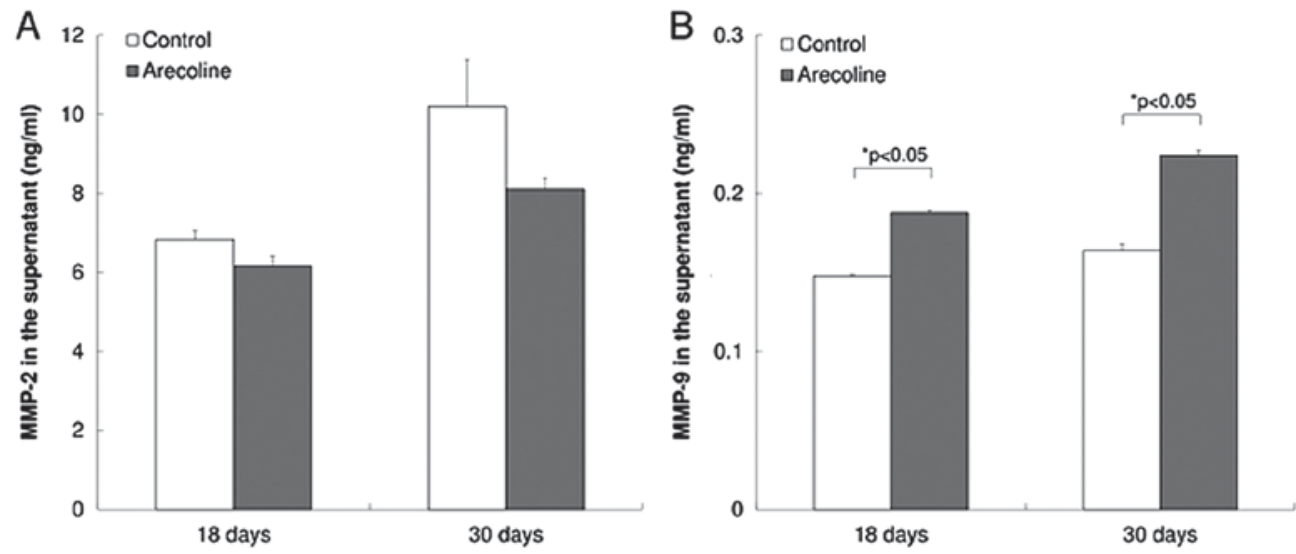

Figure 4. MMP-2 and MMP-9 activity assays in the supernatant of cultured HGEPs. MMP-2 and MMP-9 activity were assessed with MMP-2 and MMP-9 activity assays. The supernatant was isolated from HGEPs treated with arecoline for 18 or 30 days. The supernatant without any dilution or condensation was used for these assays. (A) No significant difference in the levels of MMP-2 activity was observed between the experimental and control groups. (B) The levels of MMP-9 activity in the experimental group were significantly increased compared with in the control group ("P<0.05). MMP-9, matrix metalloproteinase-9; HGEP, human gingival epithelium progenitors.

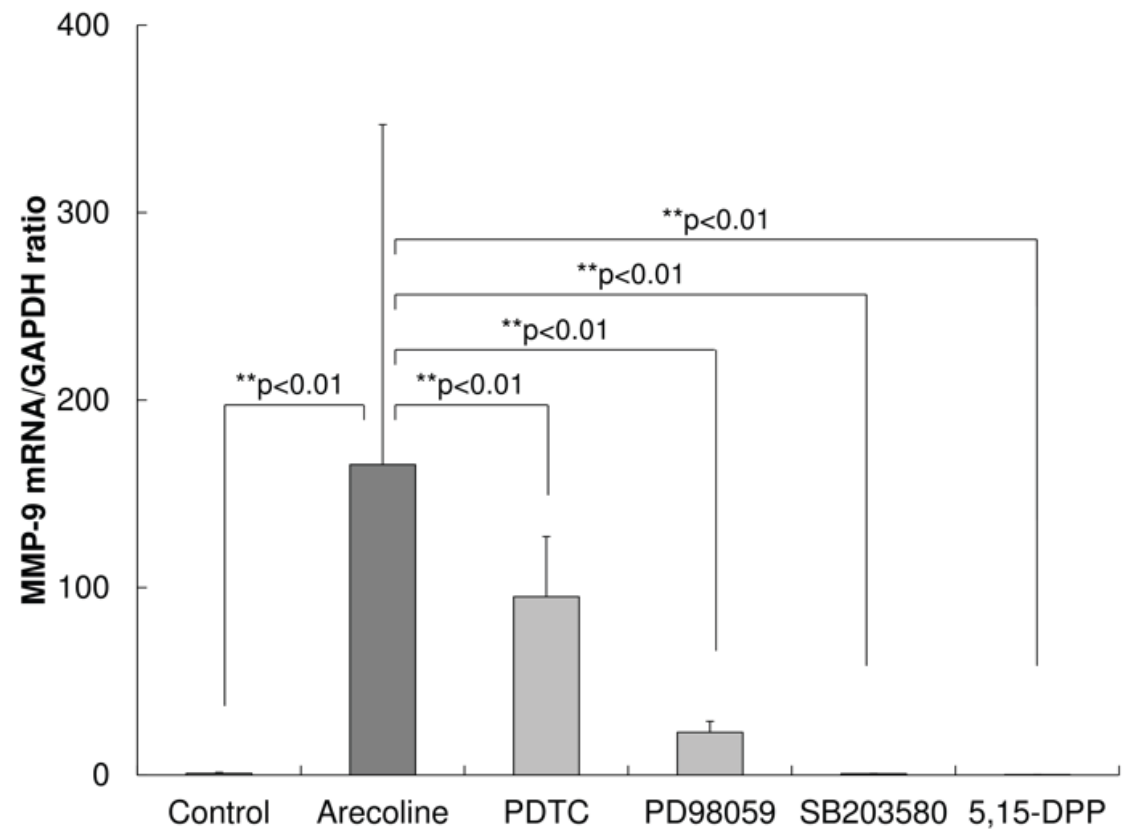

Figure 5. Effect of inhibitors on the expression of MMP-9 mRNA. To investigate which cellular signaling pathways were associated with the upregulation of MMP-9 following treatment with arecoline, inhibitors of signaling pathway were used, including the NF- $\mathrm{KB} / \mathrm{I} \mathrm{KB}$ inhibitor PDTC, the MAPK kinase inhibitor PD98059, the p38 MAPK inhibitor SB203580 and the STAT3 inhibitor 5,15-DPP. All inhibitors decreased the extent of the upregulation of MMP-9 induced by stimulation with arecoline. PDTC and PD98059 partially inhibited the upregulated expression of MMP-9, whereas SB203580 and 5,15-DPP treatments

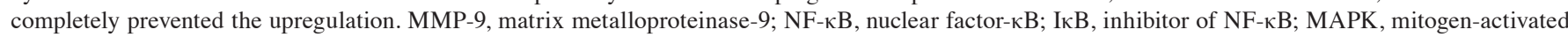
protein kinase; STAT3, signal transduction and activator of transcription 3.

cancer progression, but could not examine the initial alterations to normal cells that lead to the transformation to oral cancer and the development of precancerous lesions. In one study, normal keratinocytes were stimulated with arecoline for $\leq 24 \mathrm{~h}$ (14). Increased expression of O6-methylguanine-DNA methyltransferase was observed in primary human oral keratinocytes following stimulation with arecoline for 1-24 h (14). In a second study, activation of MMP-9 was observed in normal gingival epithelial cells stimulated with areca nut extract, also for $24 \mathrm{~h}$ (20). Since betel quid chewing is a daily habit, keratinocytes may need to be stimulated with arecoline for a prolonged period in in vitro models to simulate the habit. In the present study, an in vitro model was successfully established, in which keratinocytes derived from normal gingival epithelium were intermittently stimulated with arecoline at a concentration of $50 \mu \mathrm{g} / \mathrm{ml}$ for a month without cytotoxic effects. Immortalized keratinocytes ( $\mathrm{HaCaT}$ cells) treated with arecoline for 24,48 or $72 \mathrm{~h}$ underwent cell death at concentrations of $>50 \mu \mathrm{g} / \mathrm{ml}(8)$. The arecoline concentration used in the present study is not inconsistent with this study.

The in vitro data of the present study suggest that increased expression of MMP-9 may occur in the oral mucosa of betel quid chewers. MMPs can degrade virtually all components of the ECM and connective tissue surrounding tumor cells and 
the basement membrane (21). Among MMP type IV collagen digestive enzymes, MMP-9 is particularly important in the process of tumor invasion and metastasis $(7,22)$. High expression of MMP-9 was previously demonstrated to be associated with a poor prognosis in oral cancer (7). Increased expression levels of MMP-9 have been observed in oral precancerous lesions as well as in oral cancer (23). The increased expression may be associated with the transformation of oral precancerous lesions to oral cancer $(24,25)$ and in oral carcinogenesis (11). A previous in vitro study revealed that TNF- $\alpha$ stimulated the production of MMP-9 in a precancerous keratinocyte cell line (26). The transformation of oral precancerous lesions to cancer with micro-invasion was hypothesized as induced by inflammatory stimulation (26). In the present study, arecoline-induced MMP-9 in the keratinocytes may have caused the cells to develop the potential for micro-invasion. The production of MMP-9 from gingival epithelium was previously demonstrated to be associated with the destruction of periodontal tissues (20). Therefore, the data of the present study may explain the association of betel quid chewing with periodontal disease as well as carcinogenesis. One recent study is inconsistent with the data of the present study; in the study, although areca nut extract stimulated MMP-9 production in cancer cells, arecoline alone inhibited MMP-9 production at concentrations lower than $0.2 \mathrm{mM}(50 \mu \mathrm{g} / \mathrm{ml})$ in the oral carcinoma SAS cell line (7). The different types of cells that were used in the studies may explain this discrepancy. Arecoline induced significant cell death in SAS cells at a concentration of $0.4 \mathrm{mM}(100 \mu \mathrm{g} / \mathrm{ml})$ for $24 \mathrm{~h}$ in the previous study (7). Whereas, the present study did not identify a significant reduction in cell viability at the same concentration of arecoline at time points including $72 \mathrm{~h}$, demonstrating the extent of the differences between the cell types used. Another type of gelatinase, MMP-2, is also often upregulated in malignancies and performs an important role in tumor invasion $(12,13)$. The present results demonstrated no significant difference in the expression of MMP-2 between arecoline stimulation and the control. It is consistent with a previous study indicating that areca nut extract induces activation of MMP-9 but does not induce MMP-2 in gingival epithelial cells (20). The elevated expression of MMP-2 was, however, shown in the saliva collected from areca nut chewers (27). Keratinocytes mainly express MMP-9 and to a lesser extent MMP-2 while fibroblasts express only MMP-2 in in vitro skin models (28). The salivary MMP-2 may be mainly derived from fibroblasts in the oral mucosa. Arecoline may not affect MMP-2 activation in the gingival epithelium.

The mechanism by which arecoline may have induced the upregulation of MMP-9 was investigated using inhibitors of intercellular signaling pathways. Although all inhibitors decreased upregulated expression of MMP-9, the inhibitory effects differed. NF- $\mathrm{B} / \mathrm{I} \kappa \mathrm{B}$ and MAPK kinase inhibitors partially inhibited the upregulation of MMP-9 following treatment with arecoline, whereas p38 MAPK and STAT3 inhibitors completely abolished the upregulation. Although all these pathways may be involved in the upregulation of MMP-9, the p38 MAPK and STAT3 pathways may be more crucial than $\mathrm{NF}-\kappa \mathrm{B} / \mathrm{I} \kappa \mathrm{B}$ and MAPK kinase pathways. A number of signaling pathways, including MAPKs, NF- $\mathrm{B}$, PI3K/Akt and STAT3, were previously implicated in the production of MMP-9 by epithelial cells (29). NF- $\kappa$ B activation was identified to be involved in MMP-9 upregulation in normal gingival epithelial cells stimulated with areca nut extract at a concentration of 2.5-10 $\mu \mathrm{g} / \mathrm{ml}$ for $2 \mathrm{~h}$ (20). Although areca nut extract may activate the NF- $\mathrm{B}$ pathway for MMP-9 production, arecoline alone may act on p38 MAPK and STAT3 to a greater extent than NF- $\mathrm{B}$. Further investigations are required to determine the pathway of upregulation of MMP-9 induced by arecoline.

The activity of $>20$ types of MMPs are inhibited by just 4 types of TIMP (12). Since the activity of MMP-9 is inhibited by TIMP-1, the MMP-9/TIMP-1 ratio has been used as a diagnostic marker in numerous types of cancer and inflammation-related diseases (30). A higher ratio may signify increased degradation of the extracellular matrix in tissues related to the development and progression of cancer and inflammation (30). In the present study, the expression of MMP-9 was increased, whereas the expression levels of TIMP-1 and TIMP-2 were unchanged. This higher ratio of MMP-9/TIMP-1 may form an environment conducive to degradation of the extracellular matrix.

In conclusion, the present study demonstrated increased expression of MMP-9 caused by stimulation with arecoline for a prolonged period in primary keratinocytes derived from normal gingival epithelium. This phenomenon occurring in an in vitro experimental model may reflect the conditions in the oral mucosa of betel quid chewers. Although the increased expression level of MMP-9 may be involved in the pathological alterations of oral epithelium caused by betel quid chewing, it remains unclear how MMP-9 directly affects this process, and other genes may cooperate with MMP-9 during oral carcinogenesis. Further investigation is needed to clarify these phenomena.

\section{References}

1. Chiba I, Muthumala M, Yamazaki Y, Uz Zaman A, Iizuka T, Amemiya A, Shibata T, Kashiwazaki H, Sugiura C and Fukuda H: Characteristics of mutations in the p53 gene of oral squamous-cell carcinomas associated with betel-quid chewing in Sri Lanka. Int J Cancer 77: 839-842, 1998.

2. IARC Monographs on the Evaluation of the Carcinogenic Risk of Chemicals to Human: Tobacco Habits Other than Smoking; Betel-Quid and Areca-Nut Chewing; and Some Related Nitrosamines. Vol 37. IARC, Lyon, pp141-200, 1985.

3. Ariyawardana A, Athukorala AD and Arulanandam A: Effect of betel chewing, tobacco smoking and alcohol consumption on oral submucous fibrosis: A case-control study in Sri Lanka. J Oral Pathol Med 35: 197-201, 2006.

4. Chung $\mathrm{CH}$, Yang YH, Wang TY, Shieh TY and Warnakulasuriya S: Oral precancerous disorders associated with areca quid chewing, smoking, and alcohol drinking in southern Taiwan. J Oral Pathol Med 34: 460-466, 2005.

5. Gupta B and Johnson NW: Systematic review and meta-analysis of association of smokeless tobacco and of betel quid without tobacco with incidence of oral cancer in South Asia and the Pacific. PLoS One 9: e113385, 2014.

6. Wollina U, Verma SB, Ali FM and Patil K: Oral submucous fibrosis: An update. Clin Cosmet Investig Dermatol 8: 193-204, 2015.

7. Chang MC, Chan CP, Wang WT, Chang BE, Lee JJ, Tseng SK, Yeung SY, Hahn LJ and Jeng JH: Toxicity of areca nut ingredients: Activation of CHK1/CHK2, induction of cell cycle arrest, and regulation of MMP-9 and TIMPs production in SAS epithelial cells. Head Neck 35: 1295-1302, 2013.

8. Thangjam GS and Kondaiah P: Regulation of oxidative-stress responsive genes by arecoline in human keratinocytes. J Periodontal Res 44: 673-682, 2009. 
9. Topcu Z, Chiba I, Fujieda M, Shibata T, Ariyoshi N, Yamazaki H, Sevgican F, Muthumala M, Kobayashi H and Kamataki T: CYP2A6 gene deletion reduces oral cancer risk in betel quid chewers in Sri Lanka. Carcinogenesis 23: 595-598, 2002.

10. Takeshima M, Saitoh M, Kusano K, Nagayasu H, Kurashige Y, Malsantha M, Arakawa T, Takuma T, Chiba I, Kaku T, et al: High frequency of hypermethylation of p14, p15 and p16 in oral pre-cancerous lesions associated with betel-quid chewing in $\mathrm{Sr}$ Lanka. J Oral Pathol Med 37: 475-479, 2008.

11. Shieh DH, Chiang LC and Shieh TY: Augmented mRNA expression of tissue inhibitor of metalloproteinase-1 in buccal mucosal fibroblasts by arecoline and safrole as a possible pathogenesis for oral submucous fibrosis. Oral Oncol 39: 728-735, 2003.

12. Groblewska M, Siewko M, Mroczko B and Szmitkowski M: The role of matrix metalloproteinases (MMPs) and their inhibitors (TIMPs) in the development of esophageal cancer. Folia Histochem Cytobiol 50: 12-19, 2012

13. Herszényi L, Hritz I, Lakatos G, Varga MZ and Tulassay Z: The behavior of matrix metalloproteinases and their inhibitors in colorectal cancer. Int J Mol Sci 13: 13240-13263, 2012.

14. Lee SS, Tsai CH, Yu CC, Ho YC, Hsu HI and Chang YC: The expression of $\mathrm{O}(6)$-methylguanine-DNA methyltransferase in human oral keratinocytes stimulated with arecoline. J Oral Pathol Med 42: 600-605, 2013.

15. Chen PH, Lee KW, Hsu CC, Chen JY, Wang YH, Chen KK, Wang HM, Huang HW and Huang B: Expression of a splice variant of CYP26B1 in betel quid-related oral cancer. ScientificWorldJournal 2014: 810561, 2014.

16. Chen PH, Huang B, Shieh TY, Wang YH, Chen YK, Wu JH, Huang $\mathrm{JH}$, Chen $\mathrm{CC}$ and Lee $\mathrm{KW}$ : The influence of monoamine oxidase variants on the risk of betel quid-associated oral and pharyngeal cancer. ScientificWorldJournal 2014: 183548, 2014.

17. Takai R, Uehara O, Harada F, Utsunomiya M, Chujo T, Yoshida K, Sato J, Nishimura M, Chiba I and Abiko Y: DNA hypermethylation of extracellular matrix-related genes in human periodontal fibroblasts induced by stimulation for a prolonged period with lipopolysaccharide derived from Porphyromonas gingivalis. J Periodontal Res 51: 508-517, 2016.

18. Livak KJ and Schmittgen TD: Analysis of relative gene expression data using real-time quantitative PCR and the 2(-Delta Delta C(T)) Method. Methods 25: 402-408, 2001.

19. Rehman A, Ali S, Lone MA, Atif M, Hassona Y, Prime SS, Pitiyage GN, James EL and Parkinson EK: Areca nut alkaloids induce irreparable DNA damage and senescence in fibroblasts and may create a favourable environment for tumour progression. J Oral Pathol Med 45: 365-372, 2016.

20. Tseng YH, Chang KW, Liu CJ, Lin CY, Yang SC and Lin SC: Areca nut extract represses migration and differentiation while activating matrix metalloproteinase- 9 of normal gingival epithelial cells. J Periodontal Res 43: 490-499, 2008.

21. Lukaszewicz-Zając M, Mroczko B and Szmitkowski M: Gastric cancer - The role of matrix metalloproteinases in tumor progression. Clin Chim Acta 412: 1725-1730, 2011.

22. Li Y, Ma J, Guo Q, Duan F, Tang F, Zheng P, Zhao Z and Lu G: Overexpression of MMP-2 and MMP-9 in esophageal squamous cell carcinoma. Dis Esophagus 22: 664-667, 2009.
23. Chen Y, Zhang W, Geng N, Tian K and Jack Windsor L: MMPs, TIMP-2, and TGF-betal in the cancerization of oral lichen planus. Head Neck 30: 1237-1245, 2008.

24. Fracalossi AC, Miranda SR, Oshima CT, Franco M and Ribeiro DA: The role of matrix metalloproteinases 2 and 9 during rat tongue carcinogenesis induced by 4-nitroquinoline 1-oxide. J Mol Histol 41: 19-25, 2010.

25. Jordan RC, Macabeo-Ong M, Shiboski CH, Dekker N, Ginzinger DG, Wong DT and Schmidt BL: Overexpression of matrix metalloproteinase-1 and -9 mRNA is associated with progression of oral dysplasia to cancer. Clin Cancer Res 10: 6460-6465, 2004.

26. Hohberger L, Wuertz BR, Xie H, Griffin $\mathrm{T}$ and Ondrey F: TNF-alpha drives matrix metalloproteinase-9 in squamous oral carcinogenesis. Laryngoscope 118: 1395-1399, 2008.

27. Liu SY, Lin MH, Yang SC, Huang GC, Chang L, Chang S, Yen CY, Chiang WF, Kuo YY, Chen LL, et al: Increased expression of matrix metalloproteinase-2 in oral cells after short-term stimulation and long-term usage of areca quid. J Formos Med Assoc 104: 390-397, 2005.

28. Sawicki G, Marcoux Y, Sarkhosh K, Tredget EE and Ghahary A: Interaction of keratinocytes and fibroblasts modulates the expression of matrix metalloproteinases-2 and -9 and their inhibitors. Mol Cell Biochem 269: 209-216, 2005.

29. Lai WW, Hsu SC, Chueh FS, Chen YY, Yang JS, Lin JP, Lien JC, Tsai $\mathrm{CH}$ and Chung JG: Quercetin inhibits migration and invasion of SAS human oral cancer cells through inhibition of $\mathrm{NF}-\kappa \mathrm{B}$ and matrix metalloproteinase-2/-9 signaling pathways. Anticancer Res 33: 1941-1950, 2013.

30. Lu LC, Yang CW, Hsieh WY, Chuang WH, Lin YC and Lin CS: Decreases in plasma MMP-2/TIMP-2 and MMP-9/TIMP-1 ratios in uremic patients during hemodialysis. Clin Exp Nephrol 20: 934-942, 2016.

31. Li S, Li C, Ryu HH, Lim SH, Jang WY and Jung S: Bacitracin inhibits the migration of U87-MG Glioma cells via interferences of the integrin outside-in signaling pathway. J Korean Neurosurg Soc 59: 106-116, 2016

32. Mukhopadhyay P, Rajesh M, Bátkai S, Kashiwaya Y, Haskó G, Liaudet L, Szabó C and Pacher P: Role of superoxide, nitric oxide, and peroxynitrite in doxorubicin-induced cell death in vivo and in vitro. Am J Physiol Heart Circ Physiol 296: H1466-H1483, 2009.

33. Chen KC, Wang YS, Hu CY, Chang WC, Liao YC, Dai CY and Juo SH: OxLDL up-regulates microRNA-29b, leading to epigenetic modifications of MMP-2/MMP-9 genes: A novel mechanism for cardiovascular diseases. FASEB J 25: 1718-1728, 2011.

34. Scrideli CA, Cortez MA, Yunes JA, Queiróz RG, Valera ET, da Mata JF, Toledo SR, Pavoni-Ferreira P, Lee ML, Petrilli AS, et al: mRNA expression of matrix metalloproteinases (MMPs) 2 and 9 and tissue inhibitor of matrix metalloproteinases (TIMPs) 1 and 2 in childhood acute lymphoblastic leukemia: Potential role of TIMP1 as an adverse prognostic factor. Leuk Res 34: 32-37, 2010 . 